\title{
Spot blotch: A journey from minor to major threat of wheat
}

\author{
Debanjana Debnath $^{1}$, Sunanda Chakraborty ${ }^{2}$ and Sunita Mahapatra ${ }^{2 *}$ \\ ${ }^{1}$ Faculty of Agriculture, Sri Sri university, Cuttack, Odisha, India \\ ${ }^{2}$ Department of Plant Pathology, BCKV, W.B., India
}

\section{Article history:}

Received: 3 Oct., 2021

Revised: 28 Nov., 2021

Accepted: 16 Dec., 2021

\section{Citation:}

Debnath D, S Chakraborty and S Mahapatra. 2021. Spot blotch: A journey from minor to major threat of wheat. Journal of Cereal Research 13(3): 255-269. http://doi.org/10.25174/25822675/2022/112851

\section{*Corresponding author: \\ E-mail: sunitamahapatra@yahoo.co.in}

(C) Society for Advancement of Wheat and Barley Research

\begin{abstract}
In the recent times, the rapidly changing climate has transformed the host-pathogen-environment interactions considerably, leading to minor pathogens, such as Bipolaris sorokiniana, emerging as a major threat. B. sorokiniana attacks leaves, stem, sheath, root and grains of wheat which causes significant yield loss. However, lack of precise forecasting models, limited resistant cultivars and inadequate knowledge of new technologies for disease management serves as limitations in the proper management of the disease. In this article, we discuss the pathogen biology, its host range, host pathogen interactions, trend of severity, prevalence area, changing weather condition, newly reported resistant line/germplasm, gene and some other ecological sound approaches of the management.
\end{abstract}

Keyword: Cereals, disease resistance, management, taxonomy, Wheat.

\section{Introduction}

From time immemorial, cereals have been the most reliable source of energy and nutrition, making it the staple food of majority of people throughout the world. However, the cereals are prone to a multiple number of the pathogens, among which Bipolaris sorokiniana (Sacc.) Shoemaker (1959) [teleomorph, Cochliobolus sativus (S. Ito \& Kurib.) Drechsler ex Dastur] is a notable one. It is known as a cereal pathogen as its host range mainly comprises of cereals and grasses that belong to Gramineae family, although infections on other agronomical crops and dicots have been reported (Gupta et al., 2018a; Acharya et al., 2011; Ghazvini, 2018). The warmer parts of the continents are generally dominated by this pathogen, while the pathogen is most devastating in India in the wheat growing belts of Punjab, Uttar Pradesh, Bihar and West Bengal (Acharya et al., 2011). Bipolaris sorokiniana generally produces a wide array of symptoms, viz, leaf spot/blotch/blight, black point and common root rot in infected hosts (Kumar et al., 2019; Al-Sadi et al., 2021). Although a number of published works are available on the pathogen, a preview of the prevalence, disease severity, increasing losses, and recent changes in adaptability of the pathogen to warmer climatic conditions is the need of the hour.

This review aims at drawing attention of the researchers towards the growing significance of Bipolaris sorokiniana and identifying the recent as well as ecologically sound management practices. The review describes the latest taxonomy, significance, host range, symptomatology and epidemiology of the pathogen. The host-pathogen interactions and pathogen variability has been discussed briefly, to develop a deeper understanding of the pathogen. Finally, the effective management strategies have been summarised, which would aid in minimising the impact of the pathogen on its hosts.

\subsection{Taxonomical position}

Bipolaris sorokiniana (Sacc.) Shoemaker, 1959 has had a number of synonyms over the years. According to Shoemaker (1959), Bipolaris is merely the generic name for the species Helminthosporium having the characteristic 
fusoid, straight, or curved conidia featured with the bipolar germination. The pathogen that causes spot blotch was initially a part of the former genus Helminthosporium, but it was separated later (Fig. 1) (Kumar et al., 2020).

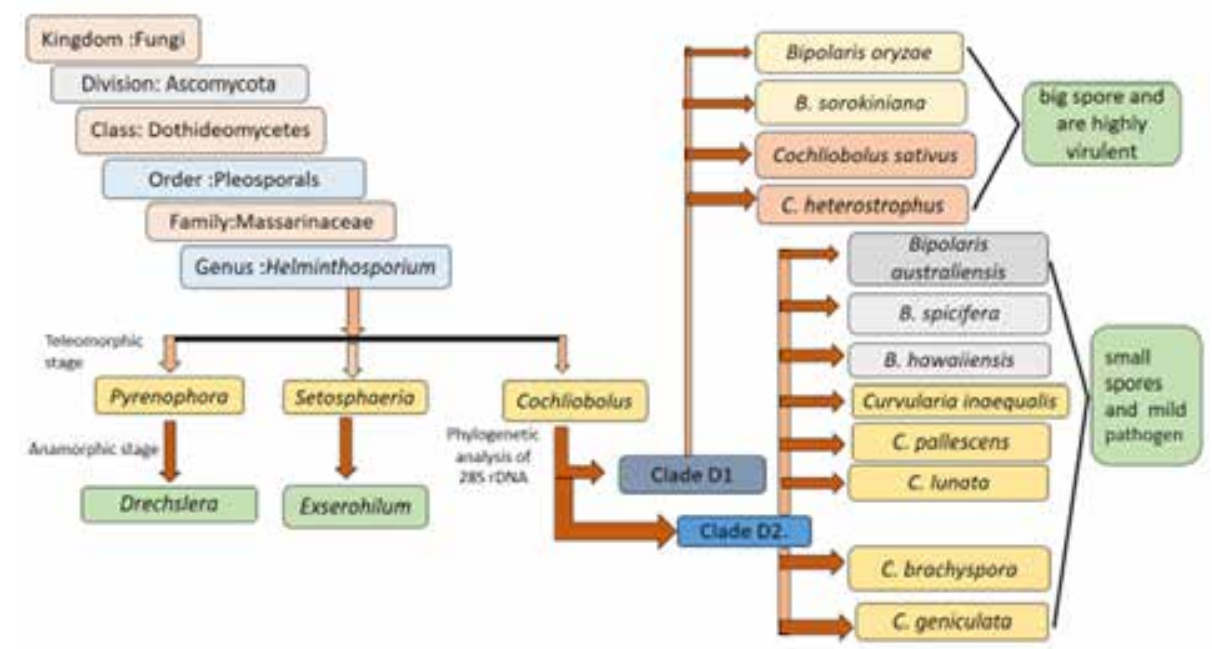

Fig. 1. Taxonomic position of Bipolaris sorokiniana

Through the analysis of gene sequences of rDNA internal transcribed spacer (ITS) region, Manamgoda et al. (2011) reported that $B$. sorokiniana and $C$. sativus represented the two stages of the same taxon. It was stated that anamorph and teleomorph of the same taxon can develop independently on different substrates or sometimes in different area. International Code of Botanical Nomenclature (ICBN) further supported this statement by mentioning that two separate binomials for two forms of the same pleomorphic fungus can be considered.
Kumar et al. (2020) also supported B. sorokiniana as the accepted nomenclature as Cochliobolus is prevalent in South Asia but dominated by B. sorokiniana. Moreover, the pathogen germination is bipolar, which makes Bipolaris sorokiniana as the preferable name as compared to Cochliobolus. The genus Bipolaris belongs to Division Ascomycota, Sub-Division Loculoascomycete, Class Dothideomycetes, Order Pleosporales and Family Pleosporaceae (Gupta et al., 2018b). Some of the synonyms of $B$. sorokiniana that are reported and mentioned in various literatures have been described in (Table 1).

Table 1. Synonyms of Bipolaris sorokiniana

\begin{tabular}{ll}
\hline \multicolumn{1}{c}{ Synonym } & \multicolumn{1}{c}{ Reference } \\
\hline Bipolaris californica (Mackie \& G.E. Paxton) & Gornostaĭ [as 'californicum'], in Azbukina et al. (eds), Vodorosli, Gribyi \\
& Mkhi Dal'nego Vostoka (Vladivostok): 80 (1978). \\
Helminthosporium californicum & Mackie \& G.E. Paxton, Phytopathology 13: $562(1923)$ \\
Ophiobolus sativus & Ito \& Kurib, Trans. Sapporo nat. Hist. Soc. 10: 138 (1929) \\
Drechslera sorokiniana (Sacc.) & Subram. \& B.L. Jain,Curr. Sci. 35: 354 (1966) \\
Cochliobolus sativus (S. Ito \& Kurib.) & Drechsler ex Dastur, Indian J Agr Res 12: 733 (1942) \\
Helminthosporium sativum & Pammel, C.M. King \& Bakke, B. Iowa. State. Coll. 116: 180 (1910) \\
Helminthosporium acrothecioides & Lindf, Sevensk bot. Tidskr. 12: 562 (1918) \\
Helminthosporium sorokinianum & Sacc. in Sorok, Trans. Soc. Nat. Univ. Kazan 22: 15 (1890) \\
\hline
\end{tabular}

\section{The yield loss associated with spot blotch} of wheat

Bipolaris sorokiniana has devastating effect on the different wheat growing zones, especially in the areas with warmer temperature and high humidity (Table 2). Gupta et al. (2018a) also mentioned that the warmer temperature in the countries like Eastern India, Bangladesh, the Terai of Nepal, Latin America, China and Africa are most favourable for 
the occurrence of spot blotch disease and are responsible for huge yield loss. The same was reported by Chowdhury et al. (2013), who also added that the probability of the disease to flare up into an epidemic was probable in the near future. Also a relationship developed between disease severity and yield loss by Devi et al. (2018).

Table 2. Yield losses by B. sorokiniana in different regions of India in the last decade

\begin{tabular}{|c|c|c|c|c|}
\hline $\begin{array}{l}\text { Sl. } \\
\text { No }\end{array}$ & Place & Crop & $\begin{array}{l}\text { Yield loss in percentage/infected } \\
\text { area in ha }\end{array}$ & Reference \\
\hline 1 & India & Wheat & $15.5 \%$ & Dubin and van Ginkel, 1991 \\
\hline 2 & Eastern Gangetic Plains & Wheat & $18-22 \%$ & Singh et al., 1997 \\
\hline 3 & Bihar & Wheat & $\begin{array}{l}7 \text { to } 30 \% \text { and } 3 \text { to } 23 \% \text { loss in } \\
1000 \text {-grain weight }\end{array}$ & Kumar and Rai, 2018 \\
\hline$\overline{4}$ & Eastern Gangetic Plains & Wheat & 9 million hectares & CIMMYT, 2013 \\
\hline 5 & Warmer countries & Wheat & $15-25 \%$ & Gupta et al., 2018a \\
\hline 6 & $\begin{array}{l}\text { Trans-Himalayan Ladakh } \\
\text { region of India }\end{array}$ & Barley & $6 \%$ to $53 \%$ & Vaish et al., 2011 \\
\hline 7 & Eastern Gangetic Plains & Wheat & $10-50 \%$ & Chowdhury et al., 2013 \\
\hline 8 & Eastern Gangetic plains & Wheat & More than $15 \%$ & Chowdhury et al., 2021 \\
\hline
\end{tabular}

\section{Host range}

Although wheat and barley (Pokharel et al., 2021) are the most adversely affected, Bipolaris sorokiniana has been reported to infect a large number of crops. It has been reported in cereals, grasses, as well as dicots, which is enlisted in Table 3.

Table 3. Different hosts of Bipolaris sorokiniana

\begin{tabular}{ll}
\hline \multicolumn{1}{c}{ Host(s) } & References \\
\hline Wheat (Triticum aestivum L.) & Biswas and Das, 2018 \\
29 crop species including Avena sativa, Hordeum vulgare, Zea mays, Oryza sativa and several grasses & Acharya et al., 2011 \\
Avena sativa, Hordeum vulgare, Zea mays, Oryza sativa, Linum usitatissimum and wild canary grass & Naresh et al., 2015 \\
Avena sativa, Hordeum vulgare, Brassica compestris, Glycine max, Lens culinaris, Vigna radiata, Sesamum Iftikhar et al., 2009 \\
$\begin{array}{l}\text { indicum, Vigna mungo, Sorghum bicolor, Zea mays and Pennisetum amaricanum } \\
\text { Triticum aestivum, Hordeum vulgare, Avena sativa, Sorghum bicolour } \text { and a large number of other } \\
\text { grasses }\end{array}$ & Bahadar et al., 2016 \\
$\begin{array}{l}\text { Solanum lycopersicum, Abelmoschus esculentus, Zea mays convar. saccharata var. rugosa, Allium } \\
\text { schoenoprasum, Musa acuminata, Solanum melongenae, Capsicum annum, Ipomoea batatas, Cenchrus } \\
\text { purpureus, Spinacia oleracea, Eleusine indica. }\end{array}$ & Ismail et al., 2020 \\
$\begin{array}{l}\text { Hordeum vulgare } \\
\text { Avena sativa, Brassica campestris, Glycine max, Lens culinaris, Pennisetum amaricanum, Sorghum } \\
\text { bicolour, Vigna radiate, Vigna mungo and Zea mays }\end{array}$ & Ghazvini 2012 \\
\hline
\end{tabular}

\section{Pathogen biology}

The pathogen, B. sorokiniana was reported to exhibit differences in conidia and conidiophore on the basis of shape, size and septation by several researches. The mycelial growth as observed on PDA media is blackmat, black-fluffy, ash-mat, brownish ash-fluffy, blackish ash-mat, whitish ash-mat, greenish ash-fluffy and pinkish white-mat coloured growth depending on the isolates
(Momtaz et al., 2019). The size of the conidia ranges from 40-120 and 15-28 $\mu \mathrm{m}$ (Acharya et al., 2011).

The best medium for the highest vegetative growth (7.4 $\mathrm{cm}$ ) of B. sorokiniana was reported as supplementation of mustard leaf extract with PDA, whereas the highest sporulation $\left(45 \times 10^{4}\right.$ spores $\left./ \mathrm{ml}\right)$ was obtained by the wheat leaf extracts with PDA (Nur et al., 2019). However, sexual reproduction of $C$. sativus has been rarely reported (Sultana et al., 2018b). Cochliobolus sativus (Previously 
known as Ophiobolus sativus) known as ascogenous state of the pathogen was first observed in the presence of opposite mating types on natural media under in vitro condition (Dastur, 1942). However, this perfect stage was reported from nowhere in natural condition except Zambia (Raemaekers, 1988).

\section{Disease symptoms}

Bipolaris sorokiniana produces more or less same kind of symptoms in its cereal host mainly on the wheat and barley. The three main symptoms that can be observed in case of B. sorokiniana attack are discussed in following sections:-

\subsection{Spot blotch}

The first visually identifiable symptoms are in the form of small lesions of 1-2 mm size which starts to grow on leaves (Acharya et al., 2011). Brown coloured lesions appear, surrounded by yellow halos in the initial stages (Fig 2) (Gupta et al., 2018a; Gupta et al., 2018b). They gradually increase in size and cover the whole leaf area by coalescing together, resulting in leaf blight (Kumar et al., 2020). After abundant conidia production on old lesions under humid conditions due to result of toxin production a chlorotic streak sometimes formed on the border of the leaves (Bockus et al., 2010).

\subsection{Seedling infection and common root rot}

According to Al-Sadi and Deadman (2010) and Al-Sadi (2021) dark brown lesions are formed on coleoptiles, basal stem, crowns, sub-crown as well as on roots on infected plants. Under extreme conditions, the seedling may die immediately after emergence. Plant shows common root rot infection which results in fewer tillers and reduced grain production.

\subsection{Black point}

B. sorokiniana, when infects cereal seeds, exhibits brown to dark brown areas on basal end of the lemmas of infected grains, resulting in 'black point' or 'kernel blight'. Black point adversely affects the seed germination and seedling emergence (Al-Sadi 2021; Neupane et al., 2010; Ghosh et al., 2018; Li et al., 2019b; Chakraborty et al., 2021). Early and severe floral infection is the main cause of seedling death. Pathogen penetrates through the ovary wall and seed coat which leads to embryo abortion as well as shrivelled and fewer grains (Han et al., 2010; Acharya $e t$ al., 2011).
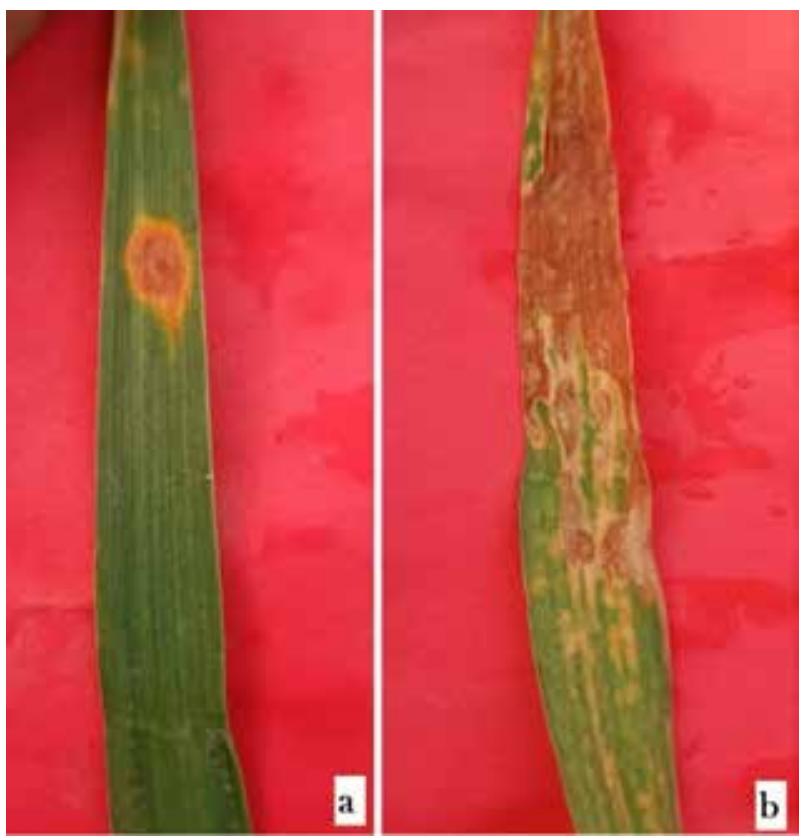

Fig 2. Symptoms produced by Bipolaris sorokiniana on infected wheat leaves; a) Initial infection in the form of small lesions; b) Lesions coalesce to give a blighted appearance

\section{Variability of the pathogen}

Variability is the inheritable difference in pathogenicity and other physiological abilities in a pathogen, which determine the extent of damage. For this reason, the genetic analysis of the existing pathogen population is used to understand the host-pathogen relationship, nature of virulence and the development of suitable management strategy.

Mann et al. (2014) isolated and tested 60 monosporic $B$. sorokiniana isolates from Brazil and other countries by using polymerase chain reaction (PCR) with universal rice primers (URP) for molecular characterization and identification of the variability among the pathogen. They observed a significant variation between isolates as well as phenotypic variations in terms of colony morphology. Mahto et al. (2012) broadly classified the 48 isolates of $C$. sativus into three groups i.e., white, light grey, and dark grey. They also observed that the isolates collected from the plains were more aggressive in nature than the isolates of hills, which indicated the dependence of host responses on the different agro climatic zone. Sultana (2018a) identified BS-24 as the highest spore producer and BS-33 having maximum PDI among the 169 isolates collected. According to the study conducted by Chauhan et al. (2017), it was concluded that among the 13 isolates collected from different part of the country, BS-2 isolates were capable of 
producing maximum lesions and highest necrotic area $(8.5$ $\mathrm{mm}^{2}$ ) in susceptible genotype, Sonalika whereas, BS-10 produced least number of lesions on the same susceptible genotype and BS-5 $\left(1.0 \mathrm{~mm}^{2}\right)$ produced the least necrotic area. This reflects the influence of pathogen variability on host responses under similar environmental conditions.

\section{Host-pathogen interactions}

Successful host pathogen interaction between the $B$. sorokiniana and the susceptible host can initiate the disease under favourable conditions (Fig 3). Acharya et al. (2011) mentioned B. sorokiniana to be an opportunistic hemi-biotrophic pathogen, which leads a biotrophic life prior to infection but can turn necrotrophic in the host body. Generally, the infection starts with the landing and germination of the spore, followed by germ tube production. The germ tube then modifies into appressorium which helps in the penetration of the infection peg (Acharya et al.2011; Domiciano et al., 2013). The duration of the onset of different event in pathogenesis has been studied by Sahu et al. (2016). They reported that the pathogen needs at least 48 hours from landing of the spore to conidia production. They also observed that initial spots occur on the leaf surface by 4 days post inoculation (DPI) and become severe by 7 DPI on the susceptible cultivar, Sonalika, at the average temperature of $18^{\circ} \mathrm{C}$. After production of the conidia, it is generally dispersed into the air causing secondary infections (Acharya et al., 2011).

This host pathogen interaction is fairly complex in nature. The cross talk of pathogenicity factors of the pathogen and the defence of the host to overcome these obstacles play a major part, and described in following sections.

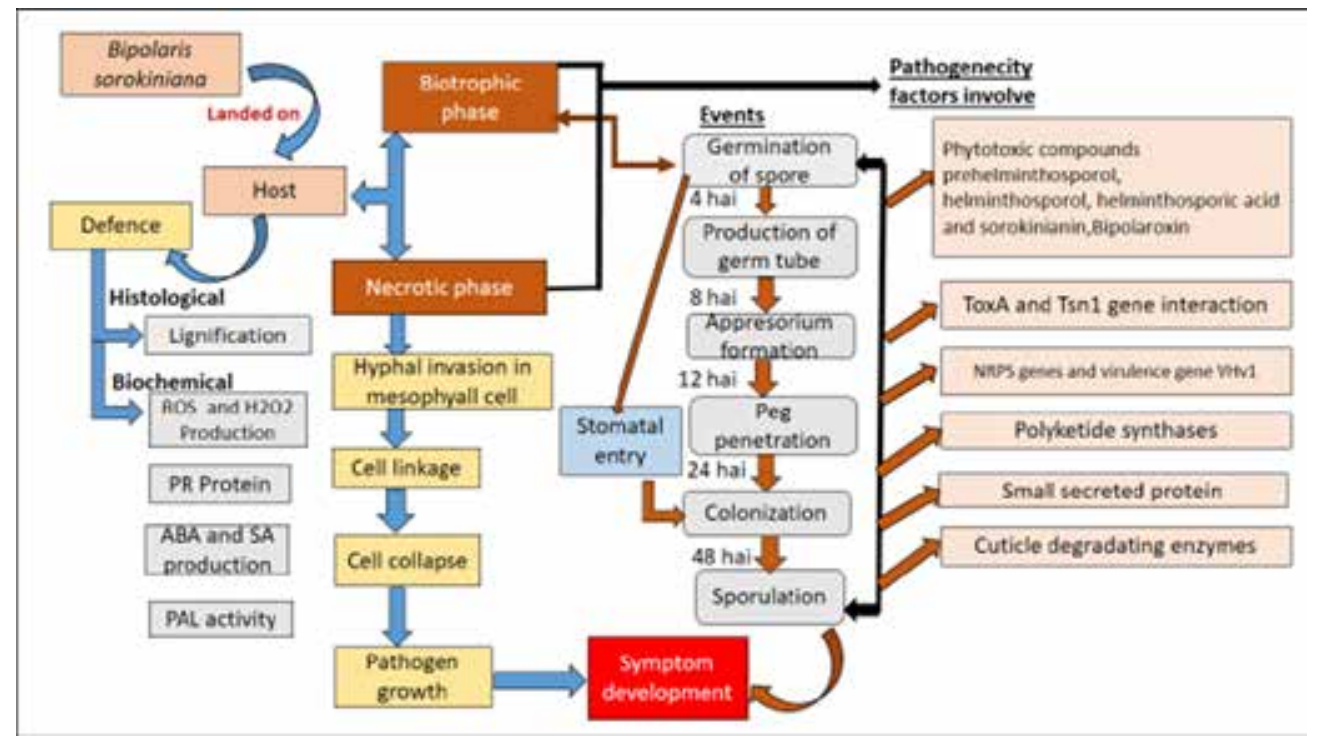

Fig. 3. Infection process of Bipolaris sorokiniana on susceptible host under favourable conditions

\subsection{Pathogenicity factor}

For increasing the chances of infection, the pathogen relies on different pathogenicity factors which impact the plant and aid in successful disease development. $\mathrm{Wu}$ et al. (2021) identified a fungal virulence factor ToxA, previously reported from Australia, USA, India and Mexico, which interact with the $T s n 1$ in wheat plant and evoke a susceptible reaction in host. By analysing 196 Mexican isolates of $B$. sorokiniana using PCR technique, they identified 20 such isolates that are able to induce necrotic reaction on the Glenlea genotype which had $T s n 1$ gene. ToxA-Tsn1 system was referred by an example of inverse Gene-for-gene relationship by Navathe et al. (2020). According to them, among the 110 isolates of B. sorokiniana collected from India, 77 isolates had ToxA positivity and 81 wheat cultivars among 220 cultivars showed $T s n 1$ gene presence. It was also revealed that seedlings having $T s n 1$ gene showed necrotic spots with yellow halo against the ToxA-containing isolates of the pathogen. The same $\operatorname{To} x A-\mathrm{Ts} n 1$ reaction was reported by Friesen et al. (2018), thus the presence of the $T s n 1$ sensitive gene helps in successful disease development by ToxA positive isolates. 
Among the different phytotoxic compounds that act as important pathogenicity factor, prehelminthosporol $\left(\mathrm{C}_{15} \mathrm{H}_{22} \mathrm{O}_{2}\right)$ is found to be the most active and abundant phytotoxin formed by the Bipolaris sorokiniana. According to Liljeroth (1998) a concentration of Helminthosporium of $30 \mathrm{\mu g} \mathrm{ml}^{-1}$ or higher quantity can significantly increase the rate of nuclear disintegration in the cells and can cause the leakage of ATP. They mentioned that filtered solution of the fungus can inhibit seedling growth $(21-73 \%)$ by direct cell damage or the parasitism of the barley roots, thus causing double trouble.

Jahani et al. (2014) reported bipolaroxin, a sesquiterpene toxin belonging to family Eremophilane isolated from $B$. sorokiniana, to be responsible for producing symptoms on wheat, barley, sorghum, maize, oats, Phalaris minor, and Cynodon dactylon even at low concentration of $30 \mathrm{ng} \mathrm{ml}^{-1}$. They observed that the isolates with low toxin producing ability had lower virulence towards plant as compared to those with higher toxin production. This led to the conclusion that the toxin produced by pathogen and their interaction with the host makes a plant susceptible or resistant.

Non-Ribosomal Peptide Synthetases (NRPSs) produced by the pathogen helps in the biosynthesis of nonribosomal peptide (NRPs) which act as a determinant of pathogenicity (Gupta et al., 2018b). They also mentioned the presence of 25 NRPS genes in the highly virulent isolate ND90Pr of C. sativus (anamorph B. sorokiniana). An association of NRPS with $\mathrm{VH} v 1$ gene was also reported which is an important pathogenicity determinant. They further mentioned the presence of polyketide synthases (PKSs) in the virulent isolate ND90Pr (pathotype 2), which helps in the synthesis of polyketides, but the role of these polyketides in pathogenicity is not clear.

\subsection{Host defence}

During the course of penetration by the pathogen, different defence mechanisms are triggered in the host. Cell lignification, which is the primary line of defence, act as a physical barrier around B. sorokiniana in infected host (Tronchet et al., 2010). The biosynthesis of lignin is regulated by ROS signalling molecules and mediated by the formation of glycosylated monolignols from L-phenylalanine, a derivative of shikimate biosynthetic pathway in the plastid (Denness et al., 2011; JacoboVelázquez et al., 2015; Marschall and Tudzynski, 2016). Poudel et al. (2019) pointed that $\mathrm{H}_{2} \mathrm{O}_{2}$ production was higher in the resistant genotypes than susceptible ones. They also reported that $\mathrm{H}_{2} \mathrm{O}_{2}$ associated lignin production significantly reduced the number of appressoria and penetration pegs formation, which led to disease resistance. Yusuf et al. (2016) and Eisa et al. (2013) came to similar conclusions when studying the association between $\mathrm{H}_{2} \mathrm{O}_{2}$ and lignification in determining the lesion area in infected plants. Janni et al. (2013) however reported a different defence mechanism whereby polygalacturonaseInhibiting Protein (PGIP) produced by the host inhibits the EndoPolygalacturonase (EPG) produced by $B$. sorokiniana. This acts as an elicitor and strengthens the host cell wall.

The wheat genes TaPIEP1, RD22, TLP4 and PR1 a have reportedly been responsible for encoding pathogeninduced ethylene responsive factor which helps in activating plant defenses against the pathogen. These genes are linked to abscisic acid (ABA) and salicylic acid (SA), which plays a crucial role in signal mediated plant defence (Dong et al., 2010; Zhang et al., 2012). Pathogenesis mediated SA accumulation in resistant plant regulate the production of a wide range of phenols and other secondary metabolites which inhibit the growth of the B. sorokiniana (Eisa et al., 2013).

Chorismate, which is also a derivative of Shikimate pathway, initiates the synthesis of pathogen-induced SA that helps in the defence of plant mainly in the biotrophic phase, whereas JA-and ET-signalling pathways control the resistance against the necrotrophic phase (Dempsey et al., 2011). On the other hand, expression of PAL1 and PAL2 increased in 12-24 hpi and 12 and 48 hpi respectively in Yangmai 6 variety of wheat.

\section{Epidemiology}

The study of epidemiology is a pre-requisite for developing an understanding of the disease severity as well as formulating disease management strategies. Sultana (2018a) indicated that the adoption of warmer temperatures by the B. sorokiniana in the South Asia during $20^{\text {th }}$ century has resulted in the development of highly virulent isolates in high ganges river flood plain agro-climatic zones. Only few regional forecasting models are developed so far (Devi et al., 2012; Viani et al., 2017; Devi et al., 2017; Tamang et al., 2021). Studies on the relationship between disease development and related weather condition are enlisted in Table 4. 
Table 4. List of epidemiological conditions for disease development

\begin{tabular}{|c|c|}
\hline Epidemiological conditions & Reference \\
\hline The optimum temperature for growth and sporulation was at $28^{\circ} \mathrm{C}$ & Naresh et al., 2015 \\
\hline High relative humidity favourable for infection and pathogen growth & Acharya et al., 2011 \\
\hline B. sorokiniana survive in moderate to warm temperatures $\left(18^{\circ} \mathrm{C}\right.$ to $\left.32^{\circ} \mathrm{C}\right)$. & Kumar et al., 2020 \\
\hline $\begin{array}{l}\text { Higher humidity (especially above } 90 \% \text { ), rain and relatively lower temperatures }(< \\
30^{\circ} \mathrm{C} \text { ) after heading increase the severity of black point disease }\end{array}$ & Li et al., 2019a; Li et al., 2019b \\
\hline $\begin{array}{l}20^{\circ} \mathrm{C} \text { to } 30^{\circ} \mathrm{C} \text {, high humidity }(90-100 \%) \text { and long periods of leaf wetness (more than } \\
12 \text { to } 18 \text { hours) are favourable for disease development }\end{array}$ & Patsa et al., 2020 \\
\hline $\begin{array}{l}30^{\circ} \mathrm{C}, 15^{\circ} \mathrm{C} \text { and } 25^{\circ} \mathrm{C} \text { were ideal for maximum conidial germination }(92.04 \%) \text {, } \\
\text { Maximum length of unipolar germ tube }(26.28 \mu \mathrm{m}) \text { and maximum width of unipolar } \\
\text { germinated germ tube }(4.49 \mu \mathrm{m}) \text { formation respectively. }\end{array}$ & Patsa et al., 2018. \\
\hline $\begin{array}{l}\text { Colony growth was slower in dark condition and colonies were dark black at } 25^{\circ} \mathrm{C} \text {. } \\
\text { In light condition, whitish fluffy colony, round mycelial growth formed and the rate } \\
\text { of growth was also higher. }\end{array}$ & Bashyal et al., 2010 \\
\hline
\end{tabular}

\section{Management of the disease}

For the successful management of the disease, an integrated approach is always the most preferred one because it increases the chances of disease control, helps in managing the loss below economic threshold level and minimizes the environmental pollution caused by excessive protective and eradicant chemicals. As B. sorokiniana has emerged as a major pathogen in the recent years, new and reliable technologies are also being developed for its management (Kumar et al., 2021; Chakraborty et al., 2021).

\subsection{Induced host resistance}

In terms of disease management, prevention is always better than cure. So, the scientists have shifted their focus in making the plant resistant against the disease, prior to attack by the pathogen. Plant resistance can be triggered externally by combined application of methyl jasmonate (150 $\mathrm{mg} \mathrm{L}^{-1}$ ) and Trichoderma harzianum strain UBSTH-501. This not only increases the indole acetic acid (IAA) in the rhizosphere, but also enhances the activities of defense related enzymes viz, catalase, ascorbate peroxidase, phenylalanine ammonia lyase and peroxidase against $B$. sorokiniana (Singh et al., 2019).

Salicylic acid signalling enhances the expression of phenylpropanoid pathway regulating genes which leads to phenol accumulation and helps in inducing resistance against spot blotch (Sahu et al., 2016). Sharma et al. (2018) showed that salicylic acid and syringic acid helps in induced resistance of the host plant against the pathogen. External application of sillicon decreases the number of necrotic cells which thus reduces the spot blotch symptoms. Devi et al. (2019) studied the role of different inducer chemicals in management of spot blotch of wheat. They observed that $\mathrm{CuSO}_{4}\left(10^{-4} \mathrm{M}\right.$ and $\left.10^{-5} \mathrm{M}\right)$ and salicyclic acid $\left(10^{-4} \mathrm{M}\right)$ significantly reduced disease incidence as well as increased grain yield in treated plants.

\subsection{Resistance by breeding}

Breeding of the plant for the development of resistant variety is an age-old technique of disease management. Along with the conventional breeding methods, the identification of resistance gene and their incorporation in the desired germplasm using molecular approaches is gaining popularity.

Sajjid et al. (2015) screened sixty wheat advanced lines/ varieties from Punjab and Pakistan, out of which 12 lines, namely, 8C006, 8C007, 9C033; 9C035, 9C036, 7C002; 088186, 088195; 076395, 076309, V 07142 and V 05068 were identified as tolerant against B. sorokiniana. Singh $e t$ al. (2017) identified one genotype KARAWANI/4NIF3/ SOTY/NAD63/CHRIS as immune, while 31 genotypes were resistant, 75 were moderately resistant, 52 were moderately susceptible and 17 were susceptible to $B$. sorokiniana. Deepsikha et al. (2017) reported HD2888, HS375, PDW291, VL804, VL829, WH1021 and WH1105 to be highly resistant to spot blotch.

Kumari et al. (2018) reported seven varieties of wheat (IC564121, IC529684, IC443669, IC443652, IC529962, IC548325 and EC178071-331) to be highly resistant to Bipolaris sorokiniana, which could be used for identification of novel resistance gene. Singh et al. (2018) studied sixty- 
two wheat genotypes, and reported 8 genotypes (HD2967, HD-3043, HP-1102, HS-277, JAUW-598, PBW-660, PBW-692 and VL-907) to be resistant, 24 were moderately resistant while others were reported as moderately susceptible and susceptible against B. sorokiniana. Mahapatra et al. (2020a) studied the performance of 117 wheat genotypes in different zones of the country. They reported that PBW 665 from North-eastern plain zone, HI 8726(d), GW 1280(d), HI 1500, HI 8730 and MP 1259 from Central zone, Raj 4240, C 306 and K 8027 from North-Eastern Plain Zone, and NIDW 295, AKAW 4731, MACS 6222, HI 8728 and HI 8725 from peninsular zone could be used for zone specific research breeding programmes against Bipolaris sorokiniana. $\mathrm{F}_{2}$ and backcross generation of resistant varieties like Chirya-3, Mayoor, Shanghai-4, Suzhoe 128-OY, Suzhoe 1-58, Longmai and Chuanmai 18 were developed by crossing them with two susceptible varieties Sonalika and HD-2329. It was revealed that Chirya- 3 and Mayoor is governed by two dominant genes (Khan et al., 2010). Ghazvini (2014) identified four putative loci on chromosomes $1 \mathrm{H}, 3 \mathrm{H}, 5 \mathrm{H}$, and $7 \mathrm{H}$ which were associated with highly resistant spot blotch lines TR 251. In a recent study, Zhang et al. (2020) made a genetic linkage map of a spot blotch resistance gene namely, $\mathrm{Sb} 4$ and pointed its delimitation in a 7.14$\mathrm{cM}$ genetic region on 4BL between markers $\mathrm{B} 6811$ and B6901 in linkage map by the crossing between GY17' and 'Zhongyu 1211.

\subsection{Biological control}

Biological control of the pathogen is a common phenomenon in nature and is generally mediated by four types of mode of action i.e., direct parasitism, competition for food, direct effect by producing toxic or antimicrobial compound and indirect toxic effect by producing volatile compounds. Some of the effective biological control agents and their mode of action against $B$. sorokiniana are enlisted in Table 5.

Table 5. Biocontrol agents and their mode of action against B. sorokiniana

\begin{tabular}{|c|c|c|}
\hline Bio control agent & Mode of Action & Reference \\
\hline $\begin{array}{l}\text { Bacillus amyloliquefaciens, B. megaterium, } \\
\text { Trichoderma harzianum, and Epicoccum sp. }\end{array}$ & Antagonistic effect & $\begin{array}{l}\text { El-Gremi } \text { et al., } 2017 \\
\text { Mahapatra } \text { et al., } 2020\end{array}$ \\
\hline B. vallismortis & Antifungal compound & $\begin{array}{l}\text { Kaur et al., 2015; Kaur et } \\
\text { al., } 2017\end{array}$ \\
\hline Bacillus subtilis TE3 strain & $\begin{array}{l}\text { Colonizing the wheat phyllosphere } \\
\text { and the antimicrobial compounds } \\
\text { production }\end{array}$ & Villa-Rodríguez et al., 2019 \\
\hline B. safensis and Ochrobactrum pseudogrignonense & $\begin{array}{l}\text { Promotes defense enzymes such } \\
\text { as chitinase, } \beta-1,3 \text { glucanase, } \\
\text { Phenylalanine Ammonia Lyase and } \\
\text { peroxidase }\end{array}$ & Sarkar et al., 2018 \\
\hline Nocardiopsis dassonvillei & $\begin{array}{l}\text { Produce siderophores and hydrogen } \\
\text { cyanide, enhances growth of wheat } \\
\text { through the production of Indole-3- } \\
\text { Acetic Acid. }\end{array}$ & Allali et al., 2019 \\
\hline $\begin{array}{l}\text { Lysobacter enzymogenes C3 and Rhizoctonia solani } \\
\text { BNR-8-2 }\end{array}$ & $\begin{array}{l}\text { Production of chitinases, } \beta-1,3- \\
\text { glucanases and antibiotics }\end{array}$ & Eken and Yuen, 2014 \\
\hline Chaetomium globosum & $\begin{array}{l}\text { Production of secondary metabolites } \\
\text { Chaetoviridin A, which inhibits the } \\
\text { growth of B. sorokiniana. }\end{array}$ & Yue et al., 2018 \\
\hline Chaetomium globosum & $\begin{array}{l}\text { Direct antagonism and induced } \\
\text { systemic resistance by acting as Plant } \\
\text { Growth-Promoting Fungus (PGPF) }\end{array}$ & $\begin{array}{l}\text { Moya et al., 2016; Aggarwal, } \\
2011\end{array}$ \\
\hline $\begin{array}{l}\text { Mycorrhiza Glomus fasciculatum, Pseudomonas } \\
\text { fluorescens } \operatorname{sh} 4\end{array}$ & $\begin{array}{l}\text { Singly or in combination, reduces the } \\
\text { pathogen growth by direct antagonism } \\
\text { or host growth promotion }\end{array}$ & Hashemi et al., 2013 \\
\hline
\end{tabular}




\subsection{Use of botanicals}

For reducing the dependency on environmentally harmful fungicides, the scope of botanical extracts as alternatives has been studied. Botanicals are not only effective against the pathogen, but are also devoid of any negative impact on environment and ecology. Some of the efficient botanicals have been identified for controlling the $B$. sorokiniana attack. Naz et al. (2018) reported that aqueous and methanolic leaf extracts $(1.2 \% \mathrm{w} / \mathrm{v})$ of Jacaranda mimosifolia resulted in 96 to $97 \%$ inhibition against $B$. sorokiniana. In a study conducted with clove oil, ginger oil, eucalyptus oil, til oil and neem oil by Debsharma $e t$ al., (2021), clove oil exhibited strongest efficacy (55.27\%) @3000 ppm concentration, although all the botanicals inhibited the pathogen. The efficacy of garlic clove extract was reported by Magar et al. (2020) and Hasan et al. (2012) to be $52.85 \%$ and $67.50 \%$ respectively, against B. sorokiniana. Prashanth et al. (2017) obtained 100\% inhibition in spore germination with garlic clove extract. Bahadar et al. (2016) reported 97\% fungal growth inhibition with methanolic extract of flowering buds of Eucalyptus camaldulensis. Tiwari and Singh (2021) studied the efficacy of Allium sativum, Allium cepa, Ginger Zingiber officinale, Eucalyptus globulus, Azadirachta indica and Nigella sativa oil extract against $B$. sorokiniana. Eucalyptus leaf extract showed 78.82\% (highest) @10\% solution while others also showed the inhibition against the target pathogen.

\subsection{Chemical management}

Along with the different eco-friendly management practices some chemicals and molecules have been proved to be highly effective against $B$. sorokiniana infection on wheat and other host. Along with the traditional fungicides, some combinations of fungicides with plant extract and other bio control agents are also used, which are enlisted in Table 6 .

Table 6. Chemicals with effective concentrations for maintaining B. sorokiniana

\begin{tabular}{|c|c|c|c|c|}
\hline Chemical group & Chemical name & Effective dose & Remarks & Reference \\
\hline \multirow[t]{3}{*}{ Triazole } & Propiconazole & $1.5 \mathrm{~mL} / \mathrm{L}$ & Increased spike yield $97.74 \mathrm{gm}$ & Gupt et al., 2020 \\
\hline & & $1 \mathrm{ml} / 1$ & $\begin{array}{l}\text { Spot blotch reduce upto } \\
60.18 \%\end{array}$ & $\begin{array}{l}\text { Mahapatra and Das } \\
\text { 2013; Patsa } \text { et al., } 2020\end{array}$ \\
\hline & & $0.1 \%$ & $\begin{array}{l}87.77 \% \text { mycelial growth } \\
\text { inhibition isolated from barley }\end{array}$ & Kavita et al., 2017 \\
\hline $\begin{array}{l}\text { Inorganic copper } \\
\text { compound }\end{array}$ & $\begin{array}{l}\text { Copper } \\
\text { oxychloride }\end{array}$ & $400 \mathrm{ppm}$ & $\begin{array}{l}\text { Inhibited } 83 \% \text { growth of } \\
\text { mycelium of the fungus after } 10 \\
\text { days in vitro condition }\end{array}$ & Angdembe et al., 2019 \\
\hline \multirow[t]{2}{*}{ Inducers } & Salicylic acid & 300 ppm & $\begin{array}{l}\text { Maximum mycelial growth } \\
\text { inhibition of } 70- \\
80 \%\end{array}$ & Adhikary et al., 2016 \\
\hline & & $10^{-4} \mathrm{M}$ & $\begin{array}{l}\text { Total yield } 39.17 \mathrm{q} / \text { ha which } \\
\text { is } 9.17 \text { quintal more than } \\
\text { untreated plot }\end{array}$ & Devi et al., 2018 \\
\hline $\begin{array}{l}\text { Inorganic copper } \\
\text { compound }\end{array}$ & $\mathrm{CuSO}_{4}$ & $10^{-4} \mathrm{M}$ & $\begin{array}{l}\text { Total yield } 37.92 \mathrm{q} / \text { ha which is } \\
7.92 \mathrm{q} / \text { ha more than untreated } \\
\text { control }\end{array}$ & Devi et al., 2019 \\
\hline $\begin{array}{l}\text { Strobilurin }+ \\
\text { Triazole }\end{array}$ & $\begin{array}{l}\text { Azoxystrobin and } \\
\text { Tebuconazole }\end{array}$ & $\begin{array}{l}120 \mathrm{~g} / \mathrm{L}+200 \\
\mathrm{~g} / \mathrm{L}\end{array}$ & $\begin{array}{l}18 \% \text { higher yields than the } \\
\text { control }\end{array}$ & Pittner et al., 2019 \\
\hline
\end{tabular}

\section{Conclusion and future aspects}

History has proven that minor diseases transform into major threats with the passage of time. Disease outbreak is regulated by different factors like favourable weather condition, availability of susceptible host and increased pathogens virulence, B. sorokiniana being no exception. A number of effective and reliable disease control measures have been developed, but their proper integration is the need of the hour. If extensive research is performed on identifying other rapid management strategies for reducing the extent of the pathogen in the near future, then our 
effort for drawing attention of the researchers through this article would be fruitful.

\section{Conflict of interest}

The authors declare that they have no conflict of interest

\section{Author contribution}

All the authors are equally contributed for this review article. SM made the concept of the article, DD and SC wrote according to the concept.SM finally edited and correspond to the journal.

\section{References}

1. Acharya K, AK Dutta and P Pradhan. 2011. Bipolaris sorokiniana (Sacc.) Shoem: the most destructive wheat fungal pathogen in the warmer areas. Australian Journal of Crop Science 5:1064-1071.

2. Adhikary SK, KG Quddus, T Samia and S Sultana. 2016. Effect of fungicides against Bipolaris sorokiniana isolates collected from different wheat growing regions of Bangladesh. Mycopathology 13(2):81-88.

3. Aggarwal R, S Gupta, VB Singh and S Sharma. 2011. Microbial detoxification of pathotoxin produced by spot blotch pathogen Bipolaris sorokiniana infecting wheat. Journal of plant biochemistry and biotechnology 20(1):66-73.

4. Allali K, Y Goudjal, M Zamoum, K Bouznada, N Sabaou and A Zitouni. 2019. Nocardiopsis dassonvillei strain MB22 from the Algerian Sahara promotes wheat seedlings growth and potentially controls the common root rot pathogen Bipolaris sorokiniana. Journal of Plant Pathology 101(4):1115-1125.

5. Al-Sadi AM and ML Deadman. 2010. Influence of seed-borne Cochliobolus sativus (Anamorph Bipolaris sorokiniana) on crown rot and root rot of barley and wheat. Journal of Phytopathology 158(10):683-690.

6. Al-Sadi AM. 2021. Bipolaris sorokiniana-induced black point, common root rot, and spot blotch diseases of wheat: A Review. Frontiers in Cellular and Infection Microbiology 11:118.

7. Angdembe B, N Dhakal, SGC Pant and HK Manandhar. 2019. in-vitro evaluation of commercially available fungicides against Bipolaris sorokiniana, the cause of spot blotch of barley. Journal of Agriculture and Forestry University 3: 105-111.
8. Bahadar K, A Munir and S Asad. 2016. Management of Bipolaris sorokiniana the causal pathogen of spot blotch of wheat by eucalyptus extracts. Journal of Plant Pathology and Microbiology 7(1):1000326.

9. Bashyal BM, R Chand, C Kushwaha, D Sen, LC Prasad and AK Joshi. 2010. Association of melanin content with conidiogenesis in Bipolaris sorokiniana of barley (Hordeum vulgare L.). World journal of Microbiology and Biotechnology 26(2):309-316.

10. Biswas A and S Das. 2018. Morphological Characterization of Bipolaris sorokiniana Infecting Wheat. International Journal of Current Microbiology and Applied Sciences 7(8): 225-248.

11. Bockus W, RL Bowden, RM Hunger, WL Morill, TD Murray and RW Smiley. 2010. Compendium of wheat diseases and pests. APS Press, St. Paul, Minnesota, 171.

12. Chakraborty S, S Kumar, S Kumar and S Mahapatra. 2021. Fungal foes: Precision phenotyping for better management of fungi borne wheat diseases. In: Bishnoi et al. Eds. Breeding frontiers in wheat. Volume 1 Agrobios (India) pp. 397-420.

13. Chauhan PK, DP Singh and SS Karwasra. 2017. Morphological and pathogenic variability in Bipolaris sorokiniana causing spot blotch in wheat (Triticum aestivum, T. durum, T. dicoccum) in India. International Journal of Current Microbiology and Applied Sciences 6(11):3499-3520.

14. Chowdhury AK, G Singh, BS Tyagi, A Ojha, T Dhar and PM Bhattacharya. 2013. Spot blotch disease of wheat-a new thrust area for sustaining productivity. Journal of Wheat Research 5(2):1-11.

15. Chowdhury AK. 2021. Threatening wheat diseases in the eastern Gangetic plains: the current status of disease resistance. Indian Phytopathology 74:333-343.

16. CIMMYT. 2013. Research battles wheat spot blotch disease. Available on: https://www.cimmyt. org/research-battles-wheat-spot-blotch-disease/ [Retrieved on 17th June 2017].

17. Dastur JF. 1942. Notes on some fungi isolated from 'black point' affected kernels in the central provinces. Indian Journal of Agricultural Sciences 12: 731-742. 
18. Debsharma R, S Islam, D Debnath, S Chakraborty and S Mahapatra. 2021. Efficacy study of some botanical oils against spot blotch disease (Bipolaris sorokiniana) of wheat under In-vitro condition. International Journal of Chemical Studies 9(1): 30223028.

19. Deepshikha, Kumari B and EP Devi. 2017. Evaluation and standardization of growth stage of wheat against spot blotch caused by Bipolaris sorokiniana. Journal of Environmental Biology 38(2):277-281.

20. Dempsey DM, AC Vlot, MC Wildermuth and DF Klessig. 2011. Salicylic acid biosynthesis and metabolism. The Arabidopsis book/American Society of Plant Biologists 9:e0156. doi:10.1199/tab.0156

21. Denness L, JF McKenna, C Segonzac, A Wormit, P Madhou, M Bennett, J Mansfield, C Zipfel and T Hamann. 2011. Cell wall damage-induced lignin biosynthesis is regulated by a reactive oxygen species-and jasmonic acid-dependent process in Arabidopsis. Plant Physiology 156(3): 1364-1374.

22. Devi HM, S Mahapatra and S Das. 2018. Assessment of yield loss of wheat caused by spot blotch using regression model. Indian Phytopathology 71(2):291294.

23. Devi HM, S Mahapatra and S Das. 2019. Management of spot blotch of wheat using inducer chemicals under field conditions. Journal of Cereal Research 11(2):152-158.

24. Devi NS, S Mahapatra and S Das. 2012. Effect of dates of sowing and inorganic fertilizers on leaf blight severity of wheat caused by Alternaria triticina. $J$. Mycol Pl Pathol. 42(4): 439-442.

25. Devi HM, S Mahapatra, S Dutta and S Das. 2017. Influence of phenological growth stages and meteorological parameters on leaf blight infestation of wheat in Gangetic plains of West Bengal. Journal of Wheat Research 9(2): 101-107.

26. Domiciano GP, FA Rodrigues, A Guerra and FX Vale. 2013. Infection process of Bipolaris sorokiniana on wheat leaves is affected by silicon. Tropical Plant Pathology 38(3):258-63.

27. Dong N, X Liu, Y Lu et al., 2010. Overexpression of TaPIEP1, a pathogen-induced ERF gene of wheat, confers host-enhanced resistance to fungal pathogen
Bipolaris sorokiniana. Functional and Integrative Genomics 10:215- 26

28. Dubin HJ and M. van Ginkel.1991. The status of wheat diseases and disease research in warmer areas. In: D. A. Saunders (ed.), Wheat for Nontraditional Warmer Areas, 125-145. CIMMYT, Mexico, D.F

29. Eisa M, R Chand and AK Joshi. 2013. Biochemical and histochemical parameters associated with slow blighting of spot blotch (Bipolaris sorokiniana (Sacc.) Shoem.) in wheat (Triticum spp.). ZemdirbysteAgriculture 100:191- 198.

30. Eken C and G Yuen. 2014. Biocontrol of common root rot of wheat with Lysobacter enzymogenes and binucleate Rhizoctonia. Romanian Agricultural Research 31:309-14.

31. El-Gremi SM, IS Draz and WA Youssef. 2017. Biological control of pathogens associated with kernel black point disease of wheat. Crop Protection 91:13-19.

32. Friesen TL, DJ Holmes, RL Bowden and JD Faris. 2018. ToxA is present in the US Bipolaris sorokiniana population and is a significant virulence factor on wheat harbouring Tsn1. Plant disease 102(12):24462452 .

33. Ghazvini H. 2012. Adult plant resistance and yield loss in barley cultivars inoculated with a newlyemerged pathotype of Bipolaris sorokiniana in Manitoba, Canada. Crop Breeding Journal. 2(1):9-15.

34. Ghazvini H. 2014. Identification, by selective genotyping, of quantitative trait loci conferring resistance to Cochliobolus sativus in barley line TR 251. Crop Breeding Journal 4(1): 35-45.

35. Ghazvini H. 2018. The host-pathogen interaction between barley and causal agent of spot blotch (Bipolaris sorokiniana) disease: a review. Crop Breeding Journal 8(1): 1-15.

36. Ghosh TA, MK Biswas, CH Guin, PR Roy and KA Aikat. 2018. A review on seed borne mycoflora associated with different cereal crop seeds and their management. Plant Cell Biotechnology and Molecular Biology 19:107-17.

37. Gupt SK, R Basnet, KJ Pant, P Wagle and M Bhatta. 2020. Efficacy of Chemical and Organic Fungicides 
against Spot Blotch Management of Wheat. Journal of Plant Sciences and Crop Protection 3(1): 101.

38. Gupta PK, NK Vasistha, R Aggarwal and AK Joshi. 2018b. Biology of B. sorokiniana (syn. Cochliobolus sativus) in genomics era. Journal of Plant Biochemistry and Biotechnology 27(2):123-38.

39. Gupta PK, R Chand, NK Vasistha, SP Pandey, U Kumar, VK Mishra and AKJoshi. 2018a. Spot blotch disease of wheat: the current status of research on genetics and breeding. Plant pathology 67(3):508-531.

40. Han Q, L Huang, H Buchenauer, C Wang and Z Kang. 2010. Cytological study of wheat spike infection by Bipolaris sorokiniana. Journal of Phytopathology 158(1):22-29.

41. Hasan MM, F Ahmed, MR Islam and KF Murad. 2012. In vitro effect of botanical extracts and fungicides against Bipolaris sorokiniana, causal agent of leaf blotch of barley. Journal of Agroforestry and Environment. 6(1):83-7.

42. Hashemi SG and HR Tarighi. 2013. Study of interaction between mycorrhiza Glomus fasciculatum and Pseudomonas fluorescens on control of common root rot of wheat caused by Bipolaris sorokiniana. Journal of Plant Protection 27(2): 142-148.

43. Iftikhar S, S Asad, A Munir, A Sultan and I Ahmad. 2009. Hosts of Bipolaris sorokiniana, the major pathogen of spot blotch of wheat in Pakistan. Pakistan Journal of Botany 41(3):1433-6.

44. Ismail M, AS Juraimi, AS Idris, MH Rusli, RZR Omar and M Naquiuddin. 2020. Bipolaris sorokiniana: A potential indigenous plant pathogen to control goosegrass (Eleusine indica) in oil palm plantations. Journal of Oil Palm Research 27(2):123-138.

45. Jacobo-Velázquez DA, M González-Agüero and L Cisneros-Zevallos. 2015. Cross-talk between signalling pathways: the link between plant secondary metabolite production and wounding stress response. Scientific Reports 5(1):1-10.

46. Jahani M, R Aggarwal, S Gupta, S Sharma and P Dureja. 2014. Purification and characterization of a novel toxin from Bipolaris sorokiniana, causing spot blotch of wheat and analysis of variability in the pathogen. Cereal Research Communications 42(2):252-61.
47. Janni M, T Bozzini, I Moscetti, C Volpi and R D'Ovidio. 2013. Functional characterisation of wheat Pgip genes reveals their involvement in the local response to wounding. Plant Biology 15(6):1019-24.

48. Kaur PK, J Kaur and HS Saini. 2015. Antifungal potential of Bacillus vallismortis R2 against different phytopathogenic fungi. Spanish Journal of Agricultural research 13(2): 1-11.

49. Kaur PK, N Joshi, IP Singh and HS Saini. 2017. Identification of cyclic lipopeptides produced by Bacillus vallismortis $\mathrm{R} 2$ and their antifungal activity against Alternaria alternata. Journal of Applied Microbiology 122(1):139-52.

50. Kavita SK, KSK Pande and JK Yadav. 2017. In vitro evaluation of fungicides against Bipolaris sorokiniana causing spot blotch of barley (Hordeum vulgare L.)". InternationalJournal of Current Microbiology and Applied Sciences 6(10):4734-4739.

51. Khan H, SM Tomar and S Chowdhury. 2010. Inheritance studies on spot blotch of wheat caused by Bipolaris sorokiniana. Indian Journal of Genetics and Plant Breeding 70(3):229-233.

52. Kumar P and P Rai. 2018. Estimation of yield loss at different disease levels of spot blotch of wheat in Bihar. International Journal of Chemical Studies. 6(6):578-561

53. Kumar S, G Singhora, SC Bharadwaj, R Bala, MS Saharan, V Gupta, A Khan, S Mahapatra, M Sivasamy, V Rana, CN Misra, O Prakash, A Verma, P Sharma, I Sharma, R Chatrath and GP Singh. 2019. Multienvironmental evaluation of wheat (Triticum aestivum L.) germplasm identifies donors with multiple fungal disease resistance. Genetic Resources and Crop Evolution. DOI: 10.1007/ s10722-019-00751-3.

54. Kumar S, N Kumar, S Prajapati and S Maurya. 2020. Review on spot blotch of wheat: An emerging threat to wheat basket in changing climate. Journal of Pharmacognosy and Phytochemistry 9(2): 1985-1997.

55. Kumar S, S Mahapatra, S Chakraborty and S Mukharjee. 2021. Effect of abiotic stresses and mitigation strategy associated with their tolerance in wheat. Journal of Cereal Research 13(1): 16-37. http:// doi.org/10.25174/2582-2675 /2 021/111211 
56. Kumari J, S Kumar, N Singh, SS Vaish, S Das, A Gupta and JC Rana. 2018. Identification of new donors for spot blotch resistance in cultivated wheat germplasm. Cereal Research Communications 46(3):467-79.

57. Li QY, QQ Xu, YM Jiang, JS Niu, KG Xu and RS He. 2019b. The correlation between wheat black point and agronomic traits in the North China Plain. Crop Protection 119:17-23.

58. Li QY, SY Wang, SW Chang, KG Xu, MY Li, QQ $\mathrm{Xu}, \mathrm{YM}$ Jiang and JS Niu. 2019a. Key periods and effects of meteorological factors affecting incidence of wheat black point in the Yellow and Huai wheat area of China. Crop Protection 125:104882.

59. Liljeroth E, I Franzon-Almgren and M Gustafsson. 1994. Effect of prehelminthosporol, a phytotoxin produced by Bipolaris sorokiniana, on barley roots. Canadian Journal of Botany 72(5):558-63.

60. Magar PB, S Baidya, R Koju and S Adhikary. 2020. In-vitro evaluation of botanicals and fungicides against Bipolaris sorokiniana, causing spot blotch of wheat. Journal of Agriculture and Natural Resources 3(2):296-305.

61. Mahapatra S and S Das. 2013. Efficacy of different fungicides against spot blotch of wheat in terai region of West Bengal. Journal of Wheat Research 5(2): 7-11.

62. Mahapatra S, HM Devi, S Kumar, D Mukherjee and S Das. 2020a. Performance and stability of different zone-specific genotypes evaluated against spot blotch of wheat. International Journal of Current Microbiology and Applied Sciences 9(06):2968-81.

63. Mahapatra S, P Rayanoothala, MK Solanki and S Das. 2020. Wheat microbiome: present status and future perspective. In: Solanki M., Kashyap P., Kumari B. (eds) Phytobiomes: Current Insights and Future Vistas. Springer, Singapore. https://doi. org/10.1007/978-981-15-3151-4_8

64. Mahto BN, S Gurung, A Nepal and TB Adhikari. 2012. Morphological, pathological and genetic variations among isolates of Cochliobolus sativus from Nepal. European Journal of Plant pathology 133(2):405-17.
65. Manamgoda SD, L Cai, AH Bahkali, E Chukeatirote and DK Hyde. 2011. Cochliobolus: an overview and current status of species. Fungal Diversity 51:3-42.

66. Mann MB, E Minotto, T Feltrin, LP Milagre, C Spadari and ST Van Der Sand. 2014. Genetic diversity among monoconidial and polyconidial isolates of Bipolaris sorokiniana. Current Microbiology 69(6):874-9.

67. Marschall R and P Tudzynski. 2016. Reactive oxygen species in development and infection processes. Seminars in Cell and Developmental Biology 57:138-146.

68. Momtaz MS, S Shamsi and TK Dey. 2019. Mycelial growth variation and compatibility of the selected isolates of Bipolaris sorokiniana (Sacc.) Shoemaker. Dhaka University Journal of Biological Sciences 28(2):195-209.

69. Moya P, D Pedemonte Roman, A Susana, ME Franco and MN Sisterna. 2016. Antagonism and modes of action of Chaetomium globosum species group, potential biocontrol agent of barley foliar diseases. Boletin de la Sociedad Argentina de Botanica. 51:569-578.

70. Naresh P, SK Biswas, U Kumar and M Rajik. 2015. Effect of media, $\mathrm{pH}$, temperature, host range and fungicides on Bipolaris sorokiniana. Annals of Plant Protection Sciences 17(2):394-397.

71. Navathe S, PS Yadav, R Chand, VK Mishra, NK Vasistha, PK Meher, AK Joshi and PK Gupta. 2020. ToxA-Tsn 1 interaction for spot blotch susceptibility in Indian wheat: An example of inverse gene-forgene relationship. Plant Disease 104(1):71-81.

72. Naz R, A Nosheen, H Yasmin, A Bano and R Keyani. 2018. Botanical-chemical formulations enhanced yield and protection against Bipolaris sorokiniana in wheat by inducing the expression of pathogenesisrelated proteins. PLOS one 13(4): e0196194.

73. Neupane A, R Sharma, E Duveiller and S Shrestha. 2010. Sources of Cochliobolus sativus inoculum causing spot blotch under warm wheat growing conditions in South Asia. Cereal Research Communications 38(4):541-9.

74. Nur Ain Izzati MZ, MZ Madihah, K Nor Azizah, A Najihah and M Muskhazli. 2019. First Report of 
Bipolaris cactivora causing Brown Leaf Spot in Rice in Malaysia. Plant Disease 103(5):1021.

75. Pande KS and JK Yadav. 2017. In vitro evaluation of fungicides against Bipolaris sorokiniana causing spot blotch of barley (Hordeum vulgare L.). International Journal of Current Microbiology and Applied Sciences 6(10):4734-9.

76. Patsa R, S Goldar, D Debnath and S Hembram. 2020. Efficacy of chemical fungicides against spot blotch (Bipolaris sorokiniana) disease management of wheat in northern part of West Bengal. International Journal of Chemical Studies. 8(3): 2627-2631

77. Patsa R, S Hembram, PM Bhattacharya, S Bandyopadhyay and S Dutta. 2018. Effect of temperature, light on germination and morphological characteristics of Bipolaris sorokiniana. Indian Phytopathology 71(2):243-8.

78. Pittner E, J Marek, D Bortuli, LA Santos and A Knob, CM Faria. 2019. Defense responses of wheat plants (Triticum aestivum L.) against brown spot as a result of possible elicitors application. Arquivos do Instituto Biológico 10:86.

79. Poudel A, S Navathe, R Chand, VK Mishra, PK Singh and AK Joshi. 2019. Hydrogen peroxide prompted lignification affects pathogenicity of hemibiotrophic pathogen Bipolaris sorokiniana to Wheat. The Plant Pathology Journal 35(4):287-300.

80. Pokharel BB, MP Pandey, SK Ghimire, DB Thapa, HK Manandhar, TR Rijal, S Thapa, P Adhikari, RP Verma and S Gyawali. 2021. Screening global set of barley germplasm for resistance to spot blotch disease in the warm-humid plains of Nepal. Journal of Cereal Research 13 (1): 70-78. http://doi. org/10.25174/2582-2675/2021. 2021;111254.

81. Prashanth J, SS Vaish and S Omprakash. 2017. In vitro Studies on the direct effect of garlic cloves and different botanical extracts against Bipolaris Sorokiniana (Sacc.) Shoem causing foliar blight of wheat. Biosciences Biotechnology Research Asia 14(3):1165-8.

82. Raemaekers RH. 1988. Helminthosporium sativum: Disease complex on wheat and sources of resistance in Zambia. In: Wheat Production Constraints in
Tropical Environments (Klatt, A.R., ed.). Mexico, D.F., Mexico: CIMMYT, pp. 175-185.

83. Sahu R, M Sharaff, M Pradhan, A Sethi, T Bandyopadhyay, VK Mishra, R Chand, AK Chowdhury, AK Joshi and SP Pandey. 2016. Elucidation of defense-related signalling responses to spot blotch infection in bread wheat (Triticum aestivum L.). Plant Journal 86(1):35-49.

84. Sajjad M, M Nasir, M Idrees, S Ali, S Mahboob, I Babar Iqbal, K Ghfoor and A Hannan. 2015. Genetic potential and effect of chemicals against Bipolaris sorokiniana in wheat. Pakistan Journal of Phytopathology 27(2):181-187.

85. SarkarJ, U Chakraborty and BN Chakraborty. 2018. Induced defense response in wheat plants against Bipolaris sorokiniana following application of Bacillus safensis and Ochrobactrum pseudogrignonense. Indian Phytopathology 71(1):49-58.

86. Sharma S, R Sahu, S Navathe, VK Mishra, R Chand, PK Singh, AK Joshi and SP Pandey. 2018. Natural variation in elicitation of defense-signaling associates to field resistance against the spot blotch disease in bread wheat (Triticum aestivum L.). Frontiers in Plant Science 9:636.

87. Shoemaker A. 1959. Nomenclature of Drechslera and Bipolaris, grass parasites segregated from 'Helminthosporium'. Canadian Journal of Botany 37:879-87.

88. Singh RV, AK Singh and SP Singh. 1997. Distribution of pathogens causing foliar blight of wheat in India and neighbouring countries. In: Duveiller E, Dubin HJ, Reeves J, McNab A (eds) Proc. Int. Workshop Helminthosporium blight of wheat: spot blotch and tan spot. 9-14 February 1997, CIMMYT El Batan, Mexico, DF pp 59 - 62

89. Singh D, SP Singh, CK Singh, RK Singh, VK Singh and AP Singh. 2017. Searching of wheat genotypes for resistance against Bipolaris sorokiniana. Journal of Pharmacognosy and Phytochemistry 6(5):2181-2183.

90. Singh SK, M Singh, VK Razdan, VB Singh, AK Singh, S Gupta, R Singh, A Gupta, U Shankar, MK Pandey and R Sharma. 2018. Prevalence of Spot Blotch (Bipolaris sorokiniana) of Wheat and its Management through Host Resistance. International 
Journal of Current Microbiology and Applied Sciences 7(2):686-94.

91. Singh UB, D Malviya, S Singh, M Kumar, PK Sahu, HV Singh, S Kumar, M Roy, M Imran, JP Rai and AK Sharma. 2019. Trichoderma harzianum-and methyl jasmonate-induced resistance to Bipolaris sorokiniana through enhanced phenylpropanoid activities in bread wheat (Triticum aestivum L.). Frontiers in Microbiology 10:1697.

92. Sultana S, SK Adhikary, MM Islam and SM Rahman. 2018a. Evaluation of pathogenic variability based on leaf blotch disease development components of Bipolaris sorokiniana in Triticum aestivum and agroclimatic origin. The plant pathology journal 34(2):93-103.

93. Tamang S, S Kumar, S Das and S Mahapatra. 2021. Role of abiotic factors on disease progression of Spot blotch of Wheat. Indian Phytopathology 74(1):263-9.

94. Tiwari P and R Singh. 2021. Effect of plant extracts against Bipolaris sorokiniana under in vitro and in vivo Conditions. International Journal of Current Microbiology and Applied Sciences 10(02): 2422-2431

95. Tronchet M, C Balagué, T Kroj, L Jouanin and D Roby. 2010. Cinnamyl alcohol dehydrogenases-C and $\mathrm{D}$, key enzymes in lignin biosynthesis, play an essential role in disease resistance in Arabidopsis. Molecular Plant Pathology 11:83-92.

96. Vaish SS, SB Ahmed and K Prakash. 2011. First documentation on status of barley diseases from the high altitude cold arid trans-himalayan Ladakh region of India. Crop Protection 30(9):1129-37.

97. Viani A, P Sinha, T Sharma and LM Bhar. 2017. A model for forecasting spot blotch disease in wheat. Australasian Plant Pathology 46(6):601-9.
98. Villa-Rodriguez E, F Parra-Cota, E Castro-Longoria, J López-Cervantes and S de los Santos-Villalobos. 2019. Bacillus subtilis TE3: a promising biological control agent against Bipolaris sorokiniana, the causal agent of spot blotch in wheat (Triticum turgidum L. subsp. durum). Biological Control 132:135-43.

99. Wu L, X He, N Lozano, X Zhang and PK Singh. 2021. ToxA, a significant virulence factor involved in wheat spot blotch disease, exists in the Mexican population of Bipolaris sorokiniana. Tropical Plant Pathology 46(2):201-6.

100. Yashwant CK, GM Rao and SK Singh. 2017. Hosts of Bipolaris sorokiniana, the major pathogen of spot blotch of wheat in Uttar Pradesh. Indian Journal of Research 6(3): 593-594.

101. Yue HM, M Wang, WF Gong and LQZhang. 2018. The screening and identification of the biological control fungi Chaetomium spp. against wheat common root rot. FEMS Microbiology Letters 365(22): doi: 10.1093/femsle/fny242.

102. Yusuf CS, R Chand, VK Mishra and AKJoshi. 2016. The association between leaf malondialdehyde and lignin content and resistance to spot blotch in wheat. Journal of Phytopathology 164:896-903.

103. Zhang P, G Guo, Q Wu, Y Chen, J Xie, P Lu, B Li, L Dong, M Li, R Wang and C Yuan. 2020. Identification and fine mapping of spot blotch (Bipolaris sorokiniana) resistance gene $\mathrm{Sb} 4$ in wheat. Theoretical and Applied Genetics 133:2451-2459.

104. Zhang X, C Wang, Y Zhang, Y Sun and Z Mou. 2012. The Arabidopsis mediator complex subunit 16 positively regulates salicylate-mediated systemic acquired resistance and jasmonate/ethylene-induced defense pathways. The Plant Cell 24:4294- 309. 